\title{
A Fast Protocol for in vitro Cloning of Banana (Musa acuminata) cv. Amritpani
}

\author{
Kaberi Maharana $^{1}$, Sashikala Beura ${ }^{2 *}$ and Partha Sarathi Munsi ${ }^{1}$ \\ ${ }^{1}$ Department of Horticulture and Post-Harvest Technology, Institute of Agriculture, \\ Visva-Bharti, Sriniketan, West Bengal-731236, India \\ ${ }^{2}$ Department of Floriculture and Landscaping and Biotechnology-cum-Tissue Culture Centre, \\ College of Agriculture, OUAT, Bhubaneswar, Odisha-751003, India \\ *Corresponding author
}

\section{A B S T R A C T}

\begin{tabular}{|l|}
\hline Ke y w o r d s \\
In vitro, \\
inoculation, \\
Musa acuminate, \\
Shoot proliferation. \\
\hline Article Info \\
\hline $\begin{array}{l}\text { Accepted: } \\
\text { 07 September } 2017 \\
\text { Available Online: } \\
10 \text { October } 2017\end{array}$ \\
\hline
\end{tabular}

\section{Introduction}

Banana known for its antiquity in India, from its mention in the Ramayana (2020 BC) is an important fruit grown commercially in our country. It is interwoven in cultural heritage and its plant, leaves and fruits are auspicious in all the festive occasions, and it is a social function or worship of God. Banana serves as the staple food of millions of people across the globe providing the balanced diet. It is a rich source of carbohydrates with calorific value of 67 calories/100g of pulp. It contains various vitamins and is used for various therapeutic purposes.
Cooked tender banana is believed to assist in curing stomach ulcers. Banana skin extract is popularly used for overcoming urinary tract infection and loose motions. Banana with sugar and honey has been a popular folk medicine to combat cough. Banana is the most important among the tropical fruits, second to grapes in production. It is one of the most important fruit crops of India and covers an area of 830 thousand hectares with an annual production of 29.78 million tonnes. It plays an important role in the socio-economic development of millions of people and 
contributes about $37 \%$ to the fruit production in India (Nandwani et al., 2000).

The cultivated bananas are triploids having a basic chromosome number $\mathrm{x}=11$ and somatic chromosome number $2 n=33$. Thus, they produce parthenocarpic fruits which are seedless. Cultivated bananas have been conventionally propagated by vegetative means through suckers since their domestication. Though true-to-type plants are produced by suckers; production is marred not only by the transmission of various diseases and pests but also the bulkiness of the propagules hinders its long distance transportation.

Micropropagation in banana has gained importance in the recent years due to manifold advantages viz. uniformity of plants, freedom from viral diseases, plants give an early yield, easy for bulk transportation, faster turnover/mass production of plants all the year round. However, during field establishment, the tissue culture plants require a higher level of care than conventional planting material (Banarjee and De Langhe, 1985).

Several types of banana are adapted to the agro-climatic condition of Odisha. Traditionally the important cultivars grown in the state are Silk (Patkapura), Poovan (Champa), Cavendish group and Plantains. Recently, there has been a trend towards the cultivation of Amritpani due to high production, productivity and consumer acceptability. Thus, there is a tremendous demand for the planting materials of this variety due to its superior fruit quality.

Banana (Musa acuminata) cv. Amritpani (AAB) is propagated vegetatively through mother rhizome and suckers. The rate of multiplication is very slow as one plant produces only 4-5 suckers in a year. The underground structures are exposed to biotic stresses viz. pests and pathogens and thus, the risk of spread of infection is high. Besides, higher cost of rhizome production and tedious method of transportation, high volume of planting materials are the major constraints faced by the grower (Dharampalan et al., 2013; Sahoo et al., 2015; Parida et al., 2016).

Considering the problems associated with this important fruit crop, it is essential to find out an alternative method of propagation to bypassing the slow rate of multiplication, to reduce the cost of transportation and to bulking up of the true-to-type disease free stocks within a shorter period of time. In vitro cloning, a real method, biotechnology is considered to be the most appropriate method of propagation to fulfill all the present day requirements of the banana cv. Amritpani. Therefore, the present investigation was undertaken with the following objectives to find out the impact of plant bio-regulators on shoot initiation, shoot proliferation and effect of auxins on induction of roots from micro shoots developed in vitro of banana $\mathrm{cv}$. Amritpani.

\section{Materials and Methods}

The investigation was carried out at Biotechnology-cum-Tissue Culture Center, OUAT, Bhubaneswar. Healthy and disease free plants of Musa acuminata cv. Amritpani were maintained in the farm of Biotechnology-cum-Tissue Culture Center, OUAT, Bhubaneswar, as mother plant block for conducting in vitro research and commercial plantlet production in the laboratory. The chemicals used for the present study were analytical reagents of excel $R$ grade of Titan Biotech Ltd., Ranbaxy Laboratory Ltd., Merck (India), Qualigen Fine Chemicals, and Himedia Laboratories Ltd. (India). Auxins, Cytokinins, myo-inositol and Fe-EDTA were supplied by Sigma (USA) 
and Agar from Ranbaxy Laboratory Limited. MS Medium (Murashige and Skoog, 1962) was used throughout the investigation, required quantities of macronutrients, micronutrients, Fe-EDTA, vitamins and plant bioregulators were taken from the stock solution and required quantity of sucrose dissolved in distilled water was added fresh to the medium. The $\mathrm{pH}$ of the solution was adjusted to $5.7+0.1$ using $0.1 \mathrm{~N} \mathrm{NaOH}$ or 0.1 $\mathrm{N}$ HCL. Then volume was made up to $1 \mathrm{~L}$ with distilled water. Agar $(0.6 \%$ w/v) was added to the medium boiled and poured into the culture bottles and capped. Culture bottles containing culture medium were autoclaved for the 20 minutes at $121^{\circ} \mathrm{C}$ and 15 Psi pressure. The autoclaved medium was kept in a laminar air flow bench for cooling. All the glassware were dipped in detergent solution for overnight and washed under running tap water. They were rinsed with distilled water and then dried in an oven for $2 \mathrm{hrs}$ at $150^{\circ} \mathrm{C}$. Forceps, petridishes and scaples were thoroughly cleaned with isopropanol or rapped with paper and kept in a clean sterilized in autoclave at $15 \mathrm{psi}$ and $121^{\circ} \mathrm{C}$ for 20 minutes. The working chamber of laminar air flow cabinet was wiped with isopropanol. Filtered air (80-100 $\mathrm{cft} / \mathrm{min})$ to ensure that particles do not settle in working area was blown for 5 minutes. The sterilized materials to be used (except living tissue) were kept in the chamber and exposed to UV light for 30 minutes. While working, filtered air was continuously passed the laminar air flow cabinet. The culture was kept at $25 \pm 2{ }^{0} \mathrm{C}$ in an air conditioned room with a 16 hours light period (3000-3200 lux) supplied by fluorescent tubes and $80 \%$ relative humidity. The explants for the experiment were taken from the preestablished culture of variety Amritpani maintained in the tissue culture Laboratory. The explants were kept on sterile filter paper and carefully transferred to the MS medium containing different concentration of cytokinins BAP (5.0, 6.0 and $7.0 \mathrm{mg} / \mathrm{l})$ in combination with IAA $(0.5$ and $1.0 \mathrm{mg} / \mathrm{l})$ and in combination with NAA $(0.5$ and $1.0 \mathrm{mg} / \mathrm{l})$ for callus formation. Three replications per treatment and 10 culture per replication and 3 culture bottles per replication were marked for observation of different treatments, from the best it was further taken for shoot initiation and shoot proliferation, calli mass was divided into four equal pieces with sharp blade and each were carefully transferred to the MS medium containing different concentration of Cytokinins BAP (4.0,5.0,6.0 and $7.0 \mathrm{mg} / \mathrm{l})$ in combination with $\mathrm{Kn}(1.0 \mathrm{mg} / \mathrm{l})$ and in combination with IAA $(0.5 \mathrm{mg} / \mathrm{l})$. Healthy shoots of about 4-5 cm height were placed for rooting in MS medium fortified with different concentration of Auxins IAA $(0.5,1.0$ and 1.5 $\mathrm{mg} / \mathrm{l})$, NAA $(0.5,1.0$ and $1.5 \mathrm{mg} / \mathrm{l})$ and IBA $(0.5,1.0$ and $1.5 \mathrm{mg} / \mathrm{l})$. Observations on (1) days to callus formation, $\%$ of explant producing callus, size of the callus $(\mathrm{cm})$, nature of the callus, colour of the callus. (2) Number of multiple shoots/clump, length of shoot $(\mathrm{cm})$ at Culture and $1^{\text {st }}$ sub-culture for 30 (Days after inoculation) DAI (3) Plant height $(\mathrm{cm})$, Number of shoots (DAI/ subculture 1/subculture 2), length of shoots $(\mathrm{cm})$, number of roots/plants and average length of root/plants for 30 DAI. The raw data obtained during the experimental observations were subjected to statistical analysis as per method by Gomez and Gomez, (1984). The significance and non- significance of the treatment effect were judged with the help of ' $F$ ' variance ratio test. Calculated ' $F$ ' value was compared with the table value of ' $F$ ' at $5 \%$ level of significance.

\section{Results and Discussion}

During the present course of investigation from the data table 1 revealed that MS medium supplemented with $7.0 \mathrm{mg} / \mathrm{l} \mathrm{BAP}$ and $0.5 \mathrm{mg} / \mathrm{l}$ IAA significantly enhanced the percentage of culture producing callus (71.56 days) and the data stood at par with treatment 
$\mathrm{T}_{3}$ (MS+6.0mg/l BAP + $0.5 \mathrm{mg} / \mathrm{l} \mathrm{IAA).Days}$ to callus formation was significantly earlier (39.07days) in treatment $T_{3}$ i.e. MS medium supplemented with $\mathrm{MS}+6.0 \mathrm{mg} / \mathrm{l} \quad \mathrm{BAP}+0.5$ $\mathrm{mg} / \mathrm{l}$ IAA and the results stood at par with treatment $\mathrm{T}_{4} \quad(\mathrm{MS}+7.0 \mathrm{mg} / \mathrm{l} \quad \mathrm{BAP}+0.5 \mathrm{mg} / \mathrm{l}$ IAA).

Size of the callus (LXB) was higher (1.5X1.4 $\mathrm{cm})$ in the treatment $\mathrm{T}_{4}(\mathrm{MS}+7.0 \mathrm{mg} / \mathrm{l}$ BAP $+0.5 \mathrm{mg} / \mathrm{l}$ IAA) followed by the treatment $\mathrm{T}_{3}$ (MS+6.0mg/l BAP+0.5 mg/l IAA) and the treatment $\quad \mathrm{T}_{7} \quad(\mathrm{MS}+7.0 \mathrm{mg} / \mathrm{l} \quad \mathrm{BAP}+1.0 \mathrm{mg} / \mathrm{l}$ IAA). The treatments $T_{3}, T_{4}$ and $T_{7}$ produced greenish white colour compact calli mass.

Hence, it has been concluded that MS medium fortified with $7.0 \mathrm{mg} / \mathrm{l} \mathrm{BAP}$ and 0.5 $\mathrm{mg} / \mathrm{l}$ IAA has profound effect on callusing of banana cv. Amritpani as indicated by significant enhancement in the percentage of culture producing callus (71.56 days), early callus formation, production of greenish white compact maximum calli mass with maximum size $(1.5 \times 1.4 \mathrm{~cm})$.

A tissue culture technique involves the establishment of different cells or tissue under a suitable culture condition, in vitro cell proliferation and subsequent regeneration of plants (Vasil et al., 1982).

The data presented in table 2 shows the impact of PBR's on shoot initiation of banana cv. Amritpani, MS medium supplemented with $5.0 \mathrm{mg} / \mathrm{l} \quad$ BAP and $0.5 \mathrm{mg} / \mathrm{l}$ IAA significantly produced maximum number of multiple shoots per clump (29.77) followed by the treatment $\mathrm{T}_{6} \quad(\mathrm{MS}+4.0 \mathrm{mg} / \mathrm{l}$ $\mathrm{BAP}+1.0 \mathrm{mg} / \mathrm{l}$ Kinetin) during culturing. However, the plant height was significantly higher in the treatment $\mathrm{T}_{10}(\mathrm{MS}+4.0 \mathrm{mg} / \mathrm{l}$ $\mathrm{BAP}+0.5 \mathrm{mg} / \mathrm{l} \mathrm{IAA}$ ) and the data stood at par with $\mathrm{T}_{6}$ and $\mathrm{T}_{11}$. During subculture-1, MS medium supplied with $5.0 \mathrm{mg} / \mathrm{l} \mathrm{BAP}$ and $0.5 \mathrm{mg} / \mathrm{l}$ IAA significantly enhanced the production of multiple shoots/clump (30.03) and also during subculture-2 where number of multiple shoots/clump was 12.33.The treatment $\mathrm{T}_{10} \quad(\mathrm{MS}+4.0 \mathrm{mg} / 1 \quad \mathrm{BAP}+0.5 \mathrm{mg} / 1$ IAA) significantly increased the plant height i.e. $4.33 \mathrm{~cm}$ and $5.97 \mathrm{~cm}$ during subculture-1 and subculture- 2 respectively. The data stood at par with the treatments $T_{11}, T_{12}$ and $T_{13}$ for plant height during subculture-1. Hence, MS medium fortified with $5.0 \mathrm{mg} / \mathrm{l}$ BAP and $0.5 \mathrm{mg} / \mathrm{l}$ IAA significantly enhanced the number of multiple shoots per clump 29.77, 30.03 and 12.33 during culture, subculture-1 and subculture-2 respectively whereas, MS medium fortified with $4.0 \mathrm{mg} / 1 \mathrm{BAP}$ and 0.5 mg/l IAA significantly enhanced the plant height i.e. $3.30 \mathrm{~cm}, 4.33 \mathrm{~cm}$ and $5.97 \mathrm{~cm}$ during culture, subculture- 1 and subculture- 2 respectively.

Hence, MS medium fortified with $5.0 \mathrm{mg} / \mathrm{l}$ BAP and $0.5 \mathrm{mg} / 1$ IAA was considered to be the best for shoot proliferation whereas MS medium supplied with $4.0 \mathrm{mg} / \mathrm{l}$ BAP and 0.5 mg/l IAA was most suitable for increasing the plant height. This may be due to the ability of cytokinin to promote the growth of dicotyledon has been reported by Murashige (1977). Application of cytokinin to lateral buds encourages the differentiation of vascular traces (Moore, 1989). The effect of cytokinin on breaking the dormancy of axillary buds under in vitro condition and proliferation of axillary shoots has been reported in various bulbus plants like Hyacinth and Lilium (Hussey, 1975).

Cytokinin at moderate concentration enhances shoot developments; at higher levels it promotes multiple shoots through precocious axillary shoots formation (Ammirato, 1976). Hussain (1995) reported that BAP in general the most active cytokinin for meristem shoot tip and axillary bud culture of various species (Kar, 2015). 
Table.1 Impact of plant bio-regulators on callusing in Banana cv. Amritpani

\begin{tabular}{|c|c|c|c|c|c|c|c|c|c|}
\hline \multirow[b]{2}{*}{ Treatment } & \multicolumn{4}{|c|}{ Composition (mg/l) } & \multirow{2}{*}{$\begin{array}{c}\text { Days to } \\
\text { callus } \\
\text { formation }\end{array}$} & \multirow{2}{*}{$\begin{array}{l}\text { Percentage of } \\
\text { explant } \\
\text { producing callus }\end{array}$} & \multirow{2}{*}{$\begin{array}{c}\text { Size of } \\
\text { callus } \\
(\mathbf{L} \times \mathbf{B}) \\
(\mathrm{cm})\end{array}$} & \multirow{2}{*}{$\begin{array}{l}\text { Nature of } \\
\text { the callus }\end{array}$} & \multirow{2}{*}{$\begin{array}{l}\text { Colour of the } \\
\text { callus }\end{array}$} \\
\hline & MS & BAP & IAA & NAA & & & & & \\
\hline $\mathrm{T}_{1}$ & - & - & - & - & 2.50 & 0.00 & - & - & - \\
\hline $\mathrm{T}_{2}$ & & 5.0 & 0.5 & & 46.92 & 41.00 & $1.2 \times 1.2$ & Compact & Greenish white \\
\hline $\mathrm{T}_{3}$ & & 6.0 & 0.5 & & 65.15 & 39.07 & $1.4 \times 1.4$ & Compact & Greenish white \\
\hline $\mathrm{T}_{4}$ & & 7.0 & 0.5 & & 71.56 & 38.47 & $1.5 \times 1.4$ & Compact & Greenish white \\
\hline $\mathrm{T}_{5}$ & & 5.0 & 1.0 & & 45.0 & 41.67 & $1.4 \times 1.2$ & Compact & Greenish white \\
\hline $\mathrm{T}_{6}$ & & 6.0 & 1.0 & & 54.78 & 41.00 & $1.4 \times 1.3$ & Compact & Greenish white \\
\hline $\mathrm{T}_{7}$ & & 7.0 & 1.0 & & 61.22 & 40.67 & $1.4 \times 1.4$ & Compact & Greenish white \\
\hline $\mathrm{T}_{8}$ & & 5.0 & - & 0.5 & 52.78 & 43.00 & $1.2 \times 1.1$ & Friable & Whitish green \\
\hline $\mathrm{T}_{9}$ & & 6.0 & - & 0.5 & 43.08 & 42.67 & $1.2 \times 1.1$ & Friable & Whitish green \\
\hline $\mathrm{T}_{10}$ & & 7.0 & - & 0.5 & 48.85 & 42.00 & $1.2 \times 1.2$ & Friable & Whitish green \\
\hline $\mathrm{T}_{11}$ & & 5.0 & - & 1.0 & 52.78 & 43.37 & $1.1 \times 1.0$ & Friable & Whitish green \\
\hline $\mathrm{T}_{12}$ & & 6.0 & - & 1.0 & 50.77 & 43.07 & $1.1 \times 1.0$ & Friable & Whitish green \\
\hline $\mathrm{T}_{13}$ & & 7.0 & - & 1.0 & 37.22 & 43.00 & $1.1 \times 1.1$ & Friable & Whitish green \\
\hline $\mathrm{T}_{14}$ & & 5.0 & 0.5 & 0.5 & 37.22 & 41.10 & $1.0 \times 0.8$ & Compact & Greenish white \\
\hline $\mathrm{T}_{15}$ & & 6.0 & 0.5 & 0.5 & 35.22 & 41.00 & $1.0 \times 0.8$ & Compact & Greenish white \\
\hline $\mathrm{T}_{16}$ & & 7.0 & 0.5 & 0.5 & 48.85 & 40.93 & $1.0 \times 0.9$ & Compact & Greenish white \\
\hline $\mathrm{T}_{17}$ & & 5.0 & 0.5 & 1.0 & 39.23 & 42.60 & $0.9 \times 0.7$ & Compact & Greenish white \\
\hline $\mathrm{T}_{18}$ & & 6.0 & 0.5 & 1.0 & 35.22 & 42.03 & $0.9 \times 0.8$ & Compact & Greenish white \\
\hline $\mathrm{T}_{19}$ & & 7.0 & 0.5 & 1.0 & 37.55 & 42.00 & $0.9 \times 0.8$ & Compact & Greenish white \\
\hline $\mathrm{T}_{20}$ & & 5.0 & 1.0 & 0.5 & 30.99 & 42.33 & $1.0 \times 0.8$ & Compact & Greenish white \\
\hline $\mathrm{T}_{21}$ & & 6.0 & 1.0 & 0.5 & 35.01 & 42.03 & $1.0 \times 0.9$ & Compact & Greenish white \\
\hline $\mathrm{T}_{22}$ & & 7.0 & 1.0 & 0.5 & 37.14 & 41.87 & $1.0 \times 0.9$ & Compact & Greenish white \\
\hline $\mathrm{T}_{23}$ & & 5.0 & 1.0 & 1.0 & 30.99 & 43.63 & $0.9 \times 0.8$ & Friable & Whitish green \\
\hline $\mathrm{T}_{24}$ & & 6.0 & 1.0 & 1.0 & 30.99 & 43.03 & $0.9 \times 0.8$ & Friable & Whitish green \\
\hline $\mathrm{T}_{25}$ & & 7.0 & 1.0 & 1.0 & 37.22 & 42.90 & $0.9 \times 0.9$ & Friable & Whitish green \\
\hline $\mathrm{SE}(\mathrm{m}) \pm$ & & - & - & - & 2.08 & 0.2 & & & \\
\hline CD $5 \%$ & & - & - & - & 5.90 & 0.6 & & & \\
\hline
\end{tabular}


Table.2 Impact of plant bio-regulators on shoot initiation and proliferation in Banana cv. Amritpani

\begin{tabular}{|c|c|c|c|c|c|c|c|c|c|c|}
\hline \multirow[t]{2}{*}{ Character } & \multicolumn{4}{|c|}{ Composition (mg/l) } & \multicolumn{2}{|c|}{ Culture- 1 at 30 days } & \multicolumn{2}{|c|}{ Subculture-1 at 45 days } & \multicolumn{2}{|c|}{ Subculture-2 at 30 days } \\
\hline & MS & BAP & Kinetin & IAA & $\begin{array}{l}\text { No. of multiple } \\
\text { shoots/ clump }\end{array}$ & $\begin{array}{l}\text { Length of } \\
\text { shoot }(\mathbf{c m})\end{array}$ & $\begin{array}{l}\text { No. of multiple } \\
\text { shoots/ clump }\end{array}$ & $\begin{array}{l}\text { Length of } \\
\text { shoot }(\mathbf{c m})\end{array}$ & $\begin{array}{l}\text { No. of multiple shoots/ } \\
\text { clump }\end{array}$ & $\begin{array}{l}\text { Length of shoot } \\
(\mathrm{cm})\end{array}$ \\
\hline $\mathrm{T}_{1}$ & & - & - & - & 3.04 & 0.97 & 4.88 & 1.43 & 2.77 & 2.07 \\
\hline $\mathrm{T}_{2}$ & & 4.0 & - & - & 6.54 & 2.20 & 6.21 & 2.97 & 4.27 & 4.37 \\
\hline $\mathrm{T}_{3}$ & & 5.0 & - & - & 18.64 & 3.03 & 20.21 & 4.07 & 7.23 & 5.3 \\
\hline $\mathrm{T}_{4}$ & & 6.0 & - & - & 16.79 & 2.50 & 26.33 & 3.47 & 8.37 & 4.50 \\
\hline $\mathrm{T}_{5}$ & & 7.0 & - & - & 10.85 & 2.43 & 28.22 & 3.40 & 8.70 & 4.23 \\
\hline $\mathrm{T}_{6}$ & & 4.0 & 1.0 & - & 21.17 & 3.27 & 20.33 & 4.27 & 7.20 & 5.80 \\
\hline $\mathrm{T}_{7}$ & & 5.0 & 1.0 & - & 18.28 & 3.17 & 21.10 & 4.13 & 8.03 & 5.80 \\
\hline $\mathrm{T}_{8}$ & & 6.0 & 1.0 & - & 16.97 & 3.07 & 22.88 & 4.03 & 9.27 & 5.60 \\
\hline $\mathrm{T}_{9}$ & & 7.0 & 1.0 & - & 15.58 & 2.97 & 21.77 & 3.87 & 8.63 & 5.50 \\
\hline $\mathrm{T}_{10}$ & & 4.0 & - & 0.5 & 13.83 & 3.30 & 26.04 & 4.33 & 10.20 & 5.97 \\
\hline $\mathrm{T}_{11}$ & & 5.0 & - & 0.5 & 29.77 & 3.23 & 30.03 & 4.20 & 12.33 & 5.80 \\
\hline $\mathrm{T}_{12}$ & & 6.0 & - & 0.5 & 17.93 & 3.20 & 28.22 & 4.13 & 11.67 & 5.27 \\
\hline $\mathrm{T}_{13}$ & & 7.0 & - & 0.5 & 16.81 & 3.17 & 20.45 & 4.03 & 9.87 & 5.13 \\
\hline $\mathrm{SE}(\mathrm{m}) \pm$ & & - & - & - & 0.20 & 0.03 & 0.22 & 0.05 & 0.10 & 0.04 \\
\hline CD $5 \%$ & & - & - & - & 0.56 & 0.09 & 0.63 & 0.13 & 0.29 & 0.12 \\
\hline
\end{tabular}


Table.3 Rooting of in vitro produced plantlets of Banana cv. Amritpani

\begin{tabular}{|c|c|c|c|c|c|c|c|c|}
\hline \multirow{2}{*}{ Treatment } & \multicolumn{4}{|c|}{ Composition (mg/l) } & \multirow{2}{*}{$\begin{array}{l}\text { Plant } \\
\text { height } \\
(\mathrm{cm})\end{array}$} & \multirow{2}{*}{$\begin{array}{l}\text { No. of } \\
\text { leaves/ } \\
\text { plant }\end{array}$} & \multirow{2}{*}{$\begin{array}{l}\text { No. of } \\
\text { roots/ } \\
\text { plant }\end{array}$} & \multirow{2}{*}{$\begin{array}{c}\text { Average length } \\
\text { of root/plant } \\
(\mathrm{cm})\end{array}$} \\
\hline & MS & IAA & NAA & IBA & & & & \\
\hline $\mathrm{T}_{1}$ & & - & - & - & 2.20 & 2.72 & 1.77 & 2.37 \\
\hline $\mathrm{T}_{2}$ & & 0.5 & - & - & 5.00 & 3.35 & 3.20 & 4.50 \\
\hline $\mathrm{T}_{3}$ & & 1.0 & - & - & 4.73 & 3.50 & 4.23 & 4.67 \\
\hline $\mathrm{T}_{4}$ & & 1.5 & - & - & 4.30 & 3.33 & 3.13 & 5.30 \\
\hline $\mathrm{T}_{5}$ & & & 0.5 & - & 4.13 & 3.40 & 4.63 & 4.10 \\
\hline $\mathrm{T}_{6}$ & & & 1.0 & - & 4.53 & 4.03 & 5.33 & 4.57 \\
\hline $\mathrm{T}_{7}$ & & & 1.5 & - & 4.50 & 3.50 & 5.17 & 3.87 \\
\hline $\mathrm{T}_{8}$ & & & & 0.5 & 4.43 & 3.20 & 5.00 & 4.73 \\
\hline $\mathrm{T}_{9}$ & & & & 1.0 & 5.07 & 4.13 & 5.80 & 5.30 \\
\hline $\mathrm{T}_{10}$ & & & - & 1.5 & 3.60 & 3.10 & 4.67 & 4.87 \\
\hline $\mathrm{SE}(\mathrm{m}) \pm$ & & - & - & - & 0.05 & 0.15 & 0.09 & 0.05 \\
\hline CD $5 \%$ & & - & - & - & 0.13 & 0.41 & 0.27 & 0.15 \\
\hline
\end{tabular}

From the perusal of data presented in table 3 for root formation study of banana $\mathrm{cv}$. Amritpani it has been observed that MS medium in addition to1.0mg/l IBA significantly increased the plant height $(5.07 \mathrm{~cm})$, number of leaves per shoot (4.13),number of roots per plant (5.80) and average length of root $(5.30 \mathrm{~cm})$ and the data stood at par with the treatment $\mathrm{T}_{2}$ (MS+0.5mg/l IAA)for plant height, with treatment $\mathrm{T}_{6}(\mathrm{MS}+1.0 \mathrm{mg} / \mathrm{l} \mathrm{NAA})$ for number of leaves per plant, with the treatment $T_{8}$ (MS+0.5mg/l IBA) for number of roots per plant and with treatment $\mathrm{T}_{4}(\mathrm{MS}+1.5 \mathrm{mg} / \mathrm{l}$ IAA) for average length of the root. Hence, MS medium supplied with $1.0 \mathrm{mg} / \mathrm{l} \mathrm{IBA}$ was found to be most suitable combination for rooting in banana cv. Amritpani as it increased significantly the plant height $(5.07 \mathrm{~cm})$, number of leaves per plant $(4.13)$, number of roots per plant (5.80) and average length of root $(5.30 \mathrm{~cm})$. The present investigation revealed that auxins (IBA) help in better rooting of micro shoots and corroborated with findings of (Kar, 2015). Hussain, (1995) reported that lower levels of auxin $(0.5$ or $1.0 \mathrm{mg} / \mathrm{l} \mathrm{NAA})$ induced early rooting. The result obtained in this investigation was in agreement with Tiwari (1997-98), who stated that 1/2 MS medium supplemented with IBA successfully produced roots. MS medium supplemented with NAA developed healthy roots (Meenakshi et al., 2001) in turmeric. Treatments with auxins stimulate and show an increase in peroxidase activity, as was observed by Palai (2001). It was suggested that the auxin entered through the cut surfaces of the proliferated shoots and rapidly absorbed in the cell walls by $\mathrm{pH}$ trapping (Rubery and Sheldrake, 1973) and by influx carriers (Delbarre et al., 1996), Epstein and Ludwig-Muller (1993) reported that during the process root induction, there were two major pathways of conversion, oxidation and conjugation. Exogenous auxins applied to micro-cuttings get oxidized, resembled the enzymes involved in the wounding reaction as reported by De Klerk et al., (1999). They also indicated that IAA or IBA oxidation caused by non-specific peroxidase was related to the rooting response.

It was concluded that MS medium fortified with $7.0 \quad \mathrm{mg} / \mathrm{l} \quad \mathrm{BAP}+0.5 \quad \mathrm{mg} / \mathrm{l} \quad \mathrm{IAA}$ significantly enhanced the percentage of 
culture producing callus (71.56 days). MS media supplemented by $5.0 \mathrm{mg} / \mathrm{l} \mathrm{BAP}+0.5$ $\mathrm{mg} / \mathrm{l}$ IAA produced a maximum number of multiple shoots per clump (29.77) and MS medium fortified with $1.0 \mathrm{mg} / \mathrm{l} \mathrm{IBA}$ produced a maximum number of roots/plants (5.80), root length $(5.30 \mathrm{~cm})$. The study thus revealed vital information related to rapid in vitro propagation of banana var. Amritpani which can be very useful for mass production of banana by various commercial entrepreneurs.

\section{References}

Ammirato, P.V. 1976. Hormonal control of tuber formation in cultured axillary buds of Dioscorea bulbifera and D. alata. Plant Physiol: 57 (suppl) :66.

Banarjee, N., and De Langhe, E. 1985. A tissue culture technique for rapid clonal propagation and storage under minimal growth conditions of Musa (Banana and Plantain). Plant cell rep.4:351-354.

De Klerk, G. J., Paffen, A., Jasik, J. and Haralampieva, V. 1999. A dual effect of ethylene during rooting of apple microcuttings. In: Altman, A.; Ziv, M.; Izhar, S., eds. Plant biotechnology and in vitro biology in the 21st century. Dordrecht: Kluwer Academic Press 4144.

Delbarre, A., Muller, P., Imhoff, V.G. and Uern, J. 1996. Comparison of mechanisms controlling uptake and accumulation of 2, 4-dichlorophenoxy acetic acid, naphthalene-1-acetic acid, and indole-3-acetic acid in suspensioncultured tobacco cells. Planta. 198: 532-541.

Dharampalan, B., Renuka, S., Jisha, S., and Varghese, S. 2013. An efficient protocol for large scale plantlets production from the apical Meristem of Musa paradisica L. cv. Nendran. Int. Journal of Agriculture, Environment and Biotechnology.198: 532-541.
Epstein, E., Ludwig Muller, J. 1993. Indole -3 butiric acid in plants occurrence, synthesis, metabolism and transport. Plant physiology. 88: 382-389.

Gomez, K.A., and Gomez, A.A. 1984. Completely Randomized Design. In: Statistical procedures for Agricultural Research, $2^{\text {nd }}$ Edn. John Wiley and Sons, New York. Pp. 8-20.

Hussain, C.T.S. 1995. Response of gladiolus to rapid cloning through in vitro techniques. M.Sc thesis Kerala Agric, Univ, Vellanikkara, Thrissur.

Hussey, G. 1975. Totipotency in tissue explant and callus of some members of Liliaceae, Iridaceae and Amaryllidaceae. J. Exp. Bot. 26(91): 253-262.

Kar, D.K. 2015. In vitro seed culture of inter specific hybrid in Cymbidium spp. M.Sc Ag. Thesis, OUAT, Bhubaneswar.

Meenakshi, N., Sulikeri, G.S., Krishnamoorthy, V. and Hegde, R.V. 2001. Standardization of chemical environment for multiple shoot induction of turmeric (Curcuma longa L.) for in vitro clonal propagation. Crop Research Hisar. 22(3), 449-453.

Moore, T.C. 1989. Auxins. In: Biochemistry and Physiology of Plant Hormones. 2nd edn, 28- 93. Nurosa Publ. House. N. Delhi.

Murashige, T. 1977. Plant propagation through tissue culture. Annual Review of Plant Physiology. 25:135-166.

Murashige, T., and Skoog, F. 1962. A revised medium for rapid growth and bioassays with tobacco cultures. Physiologia Plantarum. 15(3): 473-497

Nandwani, D., Zehr, U., Zehr, B.E. and Barwale, R.B. 2000. Mass propagation and ex vitro survival of Banana cv. Barsrail through tissue culture. Gartenbauwis senchaft.65:237-240.

Palai, S.K. 2001. Studies on physiological, biochemical and molecular status in 
vitro culture of ginger (Gingiber Officinale Rosc) and turmeric (Curcuma longa L.) Ph.D thesis, Utkal University.

Parida, S.R., Beura, S., Rout, S., Beura, R. and Jagadev, P.N. 2017. Fast protocol for high frequency in vitro cloning of Banana (Musa acuminate) cv Grande Naine. Journal of Applied and Natural Science. 9(1):72-79.

Sahoo, C., Beura, S., Rout, S. and Beura, R. 2015. High frequency in vitro cloning of
Banana (Musa acuminate) cv. Grande Naine. Int. Journal of Agriculture, Environment and Biotechnology. 8(4): 945-950.

Tiwari, R.S., 1997-1998. Micropropagation of turmeric (Curcuma longa L.). Recent horticulture. 4: 145-148.

Vasil, I.K., Scowcroft, W.R., Frey, K.I. 1982. Plant improvement and somatic cell Genetics, Academic press. NY. Pp. 158178.

\section{How to cite this article:}

Kaberi Maharana, Sashikala Beura and Partha Sarathi Munsi. 2017. A Fast Protocol for in vitro Cloning of Banana (Musa acuminata) cv. Amritpani. Int.J.Curr.Microbiol.App.Sci. 6(10): 586594. doi: https://doi.org/10.20546/ijcmas.2017.610.072 